\title{
Physico-Chemical Characterization of Waters and Sediments of Basins in the Cotton Area in Benin: Case of the Alibori Basin in the Commune of Banikoara North of Benin
}

\author{
Nafiou Egbéola Chitou1,2*, Waris Kéwouyémi Chouti1,2, Jacques Kouazounde1, \\ Daouda Mama ${ }^{2}$ \\ ${ }^{1}$ Laboratoire de Chimie Inorganique et de l'Environnement, Faculté des Sciences et Techniques (FAST), Université \\ d'Abomey-Calavi, Cotonou Bénin \\ ${ }^{2}$ Laboratoire d'Hydrologie Appliquée, Faculté des Sciences et Techniques (FAST), Université d'Abomey-Calavi, Cotonou Bénin \\ Email: chitounafiou@gmail.com
}

How to cite this paper: Chitou, N.E., Chouti, W.K., Kouazounde, J. and Mama, D. (2019) Physico-Chemical Characterization of Waters and Sediments of Basins in the Cotton Area in Benin: Case of the Alibori Basin in the Commune of Banikoara North of Benin. Journal of Environmental Protection, 10, 1436-1449.

https://doi.org/10.4236/jep.2019.1011085

Received: July 11, 2019

Accepted: November 1, 2019

Published: November 4, 2019

Copyright $\odot 2019$ by author(s) and Scientific Research Publishing Inc. This work is licensed under the Creative Commons Attribution International License (CC BY 4.0).

http://creativecommons.org/licenses/by/4.0/

\begin{abstract}
The Alibori Basin, with an area of $13,400 \mathrm{~km}^{2}$, is a tributary of the Niger River in Benin. It is a river that passes through the potentially agricultural area of Benin. The waters of the river are useful for wildlife and are used for various purposes (drinking water, laundry, domestic activities). They regularly receive the discharges and drainage of the residues of the chemical fertilizers and pesticides not used by crops during the cultivation of the river and watershed bank. This study aims to assess the impact of the agricultural inputs on the quality of the waters from Alibori river on the basis of its physico-chemical characteristics and concentrations in Trace Metal Elements such as $\mathrm{Zn}, \mathrm{Pb}, \mathrm{Cd}$ and $\mathrm{Cu}$. Seven (7) sites were selected along the river. Concentrations of $\mathrm{NO}_{3}^{-}, \mathrm{NO}_{2}^{-}, \mathrm{NH}_{4}^{+}, \mathrm{SO}_{4}^{2-} \mathrm{PO}_{4}^{3-}, \mathrm{Cu}$ and $\mathrm{Zn}$ were measured using a spectrophotometer Spectrophotometer DR 2800 and that of $\mathrm{Pb}$ and Cd by Metalyse. The Metal Trace Elements were measured in the Alibori river sediments after being treated and mineralized using aqua regia. The results revealed that Alibori river characteristics varied with seasons and its waters and sediments were polluted by metals, phosphates and nitrites. The pollution of waters of the Alibori River was due to the intensive use of the chemical fertilizers and pesticides for agricultural purposes.
\end{abstract}

\section{Keywords}

Alibori River, Fertilizers, Pesticides 


\section{Introduction}

Water is the most consumed food; it is a vital element for the human being. It is necessary for health, agriculture, industry, tourism, leisure and navigation. Having water in both quality and quantity is important to ensure a safe and healthy life in the long term [1].

Despite its importance and low exploitable availability, water is subject to anthropogenic pressures that modify its quality and lead to an imbalance or disappearance of aquatic ecosystems (fauna and flora). Human activities are likely dangerously to compromise the quality of surface water and groundwater include agriculture [2] [3].

At the same time, agriculture is an important sector for global development. It is the second largest source of employment in the world. From a historical standpoint, cotton production is the main driver of the national economy growth in West Africa. Around 3 millions of people live directly and indirectly on cotton production in Benin [4]. It contributed to the earnings from official export for about 70\% in Benin and to the GDP for about 20\% in 2017 in Benin according to European Union Speech of September 2018.

At the current stage of development, the use of agricultural inputs is essential to increase the yield and protection of cotton. The negative effects from agricultural inputs were noted 20 years after their first synthesis in the 1940s [5]. Cotton production consumes about $80 \%$ of chemical fertilizers and $90 \%$ of pesticides used in Benin. To the best knowledge of several authors [2] [6] [7] [8], the use of Organochlorine pesticides (prohibited products), including endosulfan, DDT and its derivatives by farmers is common in Benin. The impacts of organochlorine pesticides on the environment in Benin were noted by these authors. For the agricultural campaign 2008-2009, about 1000,000 liters of pesticides were used to produce 210,000 tons of cotton CSPR 2010 [9] (Agbohessi, 20 11) against a production of 269,222 tons $2015-2016$ and 597,986 tons in 2017-2018 which induces an increase in pesticide use.

The dispersion of non-usable pesticides contaminates water, soil, and air; this could affect humans (toxicological) and other living organisms (ecotoxicological effects) [10]. Non-usable chemical fertilizers by plants contribute to eutrophication of water bodies and lead to anarchic proliferation of unwanted organisms (aquatic plants) [2] (Soclo, 2003). These phenomena lead to an imbalance of the ecosystem and generate pollutants that can affect the physico-chemical and biological quality of the receiving aquatic areas. It is well known that the quality of water of an aquatic ecosystem influences its biological diversity [11] [12] [13]. The impact of pollutants on the environment is complex; their toxic actions can be direct or indirect on ecosystems. The sources of the degradation of the environment and that of human health are the same. Unlike organic pollutants that are very persistent, Trace Metal Components (TMC) are persistent and may accumulate in sediments. The sources of the TMC can include phosphate based chemical fertilizers [14] [15], pesticides, and also domestic and industrial wastes 
[16]. $\mathrm{Cu}$ and $\mathrm{Zn}$, which are trace elements, can become toxic at high concentrations [17]. $\mathrm{Hg}$ and $\mathrm{Pb}$, which have no known biological utility, are dangerous and toxic even in very small quantities [18]. Thus, the water pollution by TMC is an important factor of aquatic ecosystems destruction. Sediments are often a reservoir of chemical components such as persistent organic pollutants (POPs) and metals, which fixe to suspended particles owing to their hydrophobicity and/or high affinity for organic matter or metal oxyhydroxides, [19]. The assessment of the surface water quality is based on the measurement of physico-chemical parameters, toxicity tests and the presence or absence of aquatic organisms and micro-organisms, which are indicators of water quality [20].

\section{Study Framework}

\subsection{Geographic Situation}

The river of Alibori is located north of Benin in the Sudan region between $10^{\circ} 30^{\prime}$ and $12^{\circ}$ north latitude and $1^{\circ} 32^{\prime}$ and $3^{\circ} 50^{\prime}$ East longitude. It springs at a height of about $410 \mathrm{~m}$ in the granite massif of Kita on the side of the Atacora chain in the commune of Péhenco. Of a watershed covering an area of $13,740 \mathrm{~km}^{2}$, the Alibori River is $427 \mathrm{~km}$ long (Figure 1).

\subsection{Current Situation and Sampling Campaign}

Three campaigns of field surveys were conducted to the first one held in the dry season in March 2018 and was followed by a sampling campaign. The second field survey campaign was carried out in September 2018 during the period of high water at the beginning of crops treatment by pesticides, but after application of chemical fertilizer to crops. The third campaign was conducted at the end of the rainy season in the harvest period in November. 7 sites were selected (Figure 2).

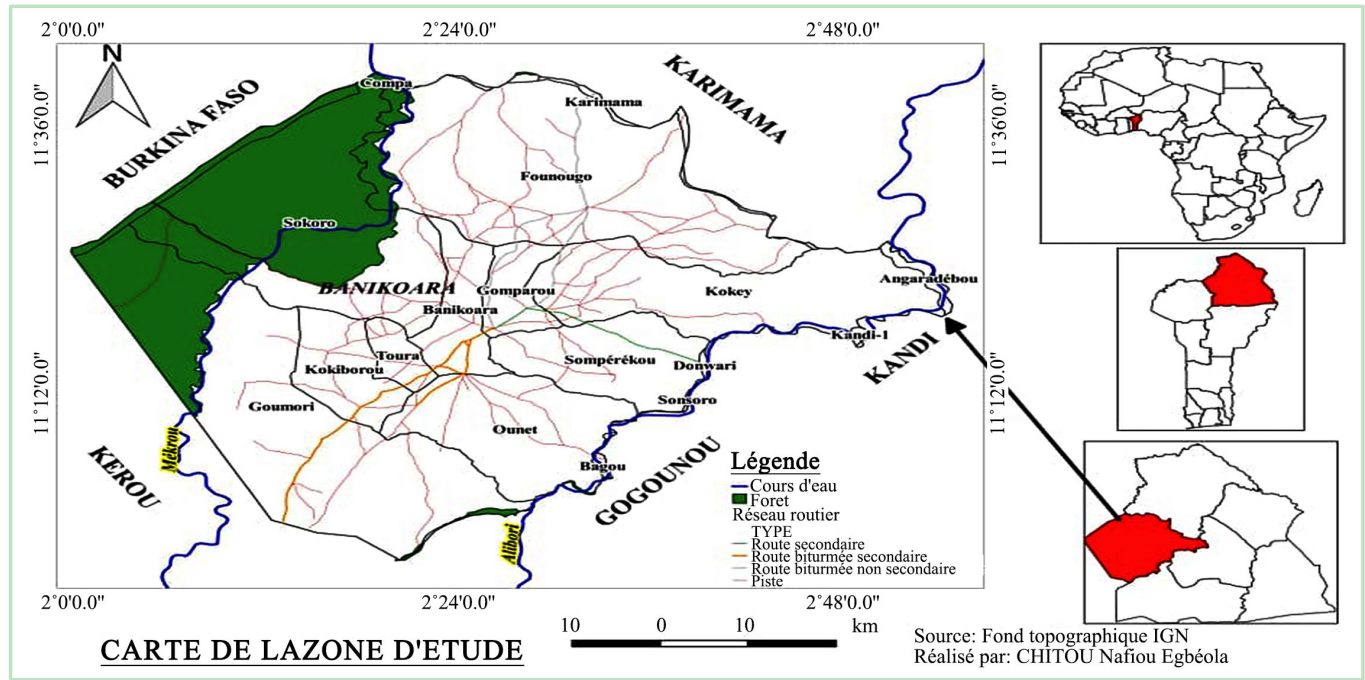

Figure 1. Geographic map of the study environment. 


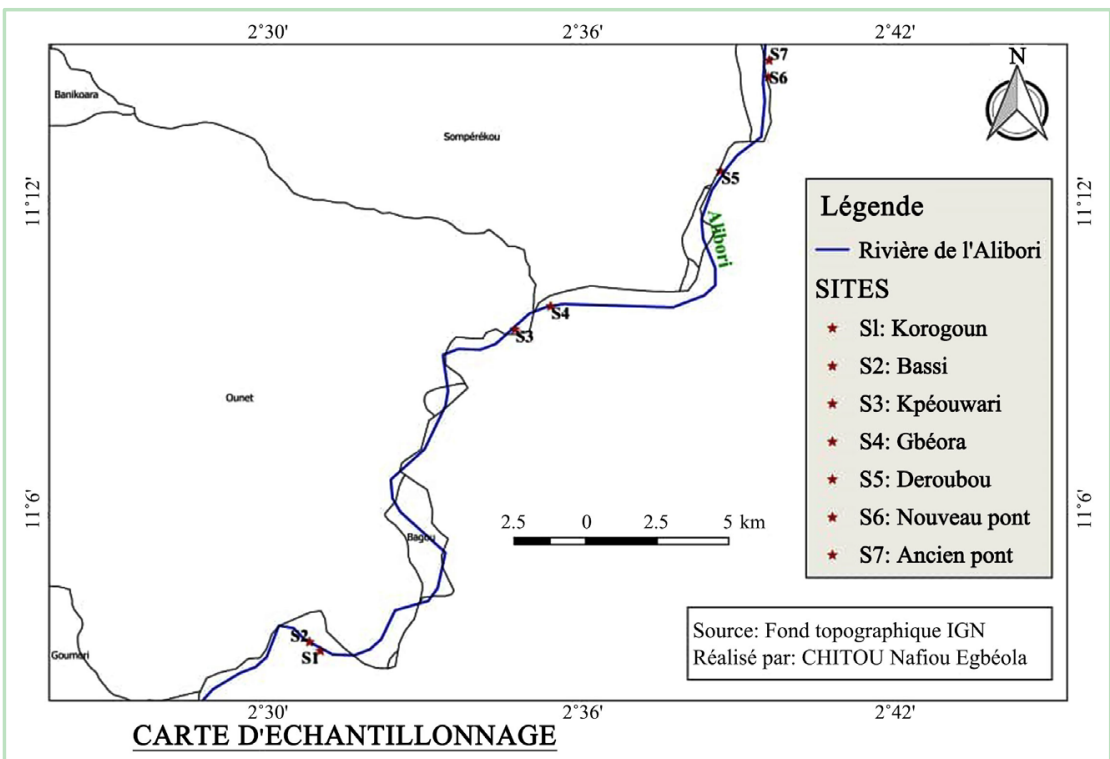

Figure 2. Sampling maps.

\section{Hardware and Methods}

Water was collected from river using $1.5-\mathrm{L}$ plastic vials, which were pre-washed with a $10 \%$ acid solution and then rinsed three times using simple water and distilled water. Prior to sampling, the plastic vials were thoroughly rinsed with the river's water from each site. Water was then collected in the washed plastic vials about $5 \mathrm{~cm}$ from the surface of the river and stored in cool boxes for use in laboratory.

Sediment was sampled from medium-depth horizons, packed in bags (polyethylene bag) and then stored in cool boxes.

\section{Sample preparation and analysis}

The Different physicochemical parameters ( $\mathrm{PH}$, temperature, TDS) were determined in the field using a multiparamètre device and $\mathrm{pH}$ meter.

The sampled water was directly analyzed in the laboratory using a DR 2800 spectrophotometer for determination of the chemical parameters including $\mathrm{NH}_{4}^{+}, \mathrm{NO}_{3}^{-}, \mathrm{NO}_{2}^{-}, \mathrm{PO}_{4}^{3-}$ as well as $\mathrm{Cu}$ and $\mathrm{Zn}$. The measurement of $\mathrm{Pb}$ and $\mathrm{Cd}$ in the water was carried using DR 3000 Metalyser.

The sampled sediments were dried at $105^{\circ} \mathrm{C}$ for 24 hours (constant weight), then crushed, sieved at $2 \mathrm{~mm}$ and homogenized. A sample of $1 \mathrm{~g}$ of the sediment was mineralized with aqua regia (mixture of hydrochloric and nitric acid), then analyzed for $\mathrm{Cu}^{2+}$ and $\mathrm{Zn}^{2+}$ using spectrophotometer $\mathrm{DR} 2800$, and for $\mathrm{Pb}$ and Cd by Métalyser.

\section{Results}

The analysis in Table 1 shows that the temperature of the river varied with season and sampling time, ranging from $24.80^{\circ} \mathrm{C}$ to $27.60^{\circ} \mathrm{C}$ during the rainy season and from $30.00^{\circ} \mathrm{C}$ to $32.00^{\circ} \mathrm{C}$ during the dry season. Thus, the temperature of the sampled water exceeded the standards of $25.00^{\circ} \mathrm{C}$ set for the dry season. 
Table 1. Physico-chemical parameters.

\begin{tabular}{cccccccccc}
\hline & \multicolumn{3}{c}{$\mathrm{T}^{\circ} \mathrm{C}$} & \multicolumn{3}{c}{$\mathrm{pH}$} & \multicolumn{3}{c}{ TDS } \\
\hline Site & SS & SP & FSP & SS & SP & FSP & SS & SP & FSP \\
\hline S1 & 31.90 & 25.00 & 24.80 & 6.37 & 6.40 & 6.90 & 168.00 & 124.00 & 114.00 \\
S2 & 31.80 & 26.00 & 25.00 & 6.60 & 6.70 & 7.20 & 165.00 & 129.00 & 116.00 \\
S3 & 31.60 & 26.50 & 26.70 & 6.53 & 6.70 & 7.40 & 166.00 & 91.00 & 115.00 \\
S4 & 30.00 & 27.00 & 25.10 & 6.32 & 6.50 & 7.30 & 147.00 & 91.00 & 116.00 \\
S5 & 31.00 & 28.00 & 27.30 & 6.47 & 6.80 & 7.40 & 218.00 & 101.00 & 118.00 \\
S6 & 32.00 & 28.00 & 27.30 & 6.49 & 6.80 & 7.30 & 228.00 & 90.00 & 117.00 \\
S7 & 32.00 & 28.70 & 27.60 & 6.62 & 7.10 & 7.20 & 213.00 & 104.00 & 118.00 \\
Moy & 31.47 & 27.02 & 26.25 & 6.48 & 6.71 & 7.20 & 186.40 & 104.28 & 116.28 \\
\hline
\end{tabular}

SS: Dry season; SP: Rainy season; FSP: End of the Rainy season.

Water $\mathrm{pH}$ increased from the dry season to the rainy season, ranging from 6.37 to 6.62 in the dry season, from 6.40 to 7.10 in the rainy season and from 6.90 to 7.40 at the end of the rainy season. Water $\mathrm{pH}$ recorded in the rainy season $(6.50$ - 8.50) was consistent with the standards set by the World Health Organization standards for drink water, by the IGBE for surface water and for water resources protection.

The TDS value recorded in the dry season is superior to that recorded in the rainy season.

\section{$\checkmark$ Nitrite}

From Figure 3, the nitrite concentrations in the river varied from $1.00 \mathrm{mg} \cdot \mathrm{L}^{-1}$ to $20.00 \mathrm{mg} \cdot \mathrm{L}^{-1}$ in the rainy season, which exceeded the standards set by WHO $\left(3 \mathrm{mg} \cdot \mathrm{L}^{-1}\right)$ and IGBE $\left(3 \mathrm{mg} \cdot \mathrm{L}^{-1}\right)$ with the exception of site 2.

\section{$\checkmark$ Nitrate}

The nitrate concentrations of the river ranged from $2 \mathrm{mg} \cdot \mathrm{L}^{-1}$ to $7.20 \mathrm{mg} \cdot \mathrm{L}^{-1}$ in the rainy season and from $0.40 \mathrm{mg} \cdot \mathrm{L}^{-1}$ to $2.25 \mathrm{mg} \cdot \mathrm{L}^{-1}$ in the dry season (Figure 4). These values were lower than the WHO standard $\left(50 \mathrm{mg} \cdot \mathrm{L}^{-1}\right)$ and the simplified assessment grid for river's water quality.

\section{Phosphate}

The analysis in Figure 5 shows that the phosphate concentrations in the river's water in the dry season were superior to those recorded in the rainy season, ranging from $1.07 \mathrm{mg} \cdot \mathrm{L}^{-1}$ to $2.53 \mathrm{mg} \cdot \mathrm{L}^{-1}$. The river's water is of poor quality according to grid-quality of surface water as the recorded concentrations in phosphate were between $1 \mathrm{mg} \cdot \mathrm{L}^{-1}$ and $5 \mathrm{mg} \cdot \mathrm{L}^{-1}$.

\section{Trace metal elements}

\section{$\checkmark$ Zinc in the waters}

From Figure 6 the $\mathrm{Zn}$ concentrations in the river's water during the dry season were higher than in the rainy season and varied from 1.51 to $4.79 \mathrm{mg} \cdot \mathrm{L}^{-1}$. They exceeded the standards set by the IBGE $\left(0.30 \mathrm{mg} \cdot \mathrm{L}^{-1}\right)$ and for heavy metal concentrations in surface waters (EC Directive). 


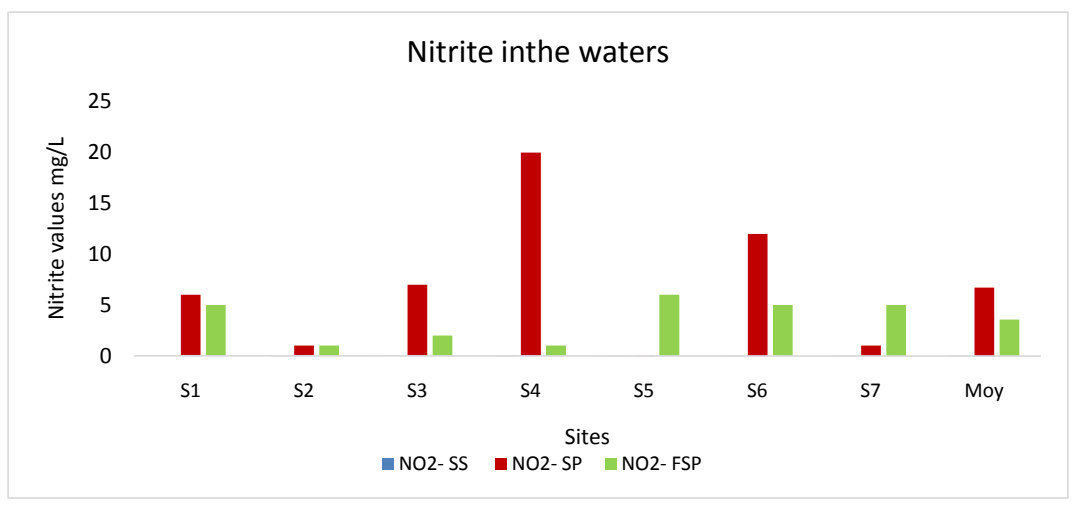

Figure 3. Nitrite values.

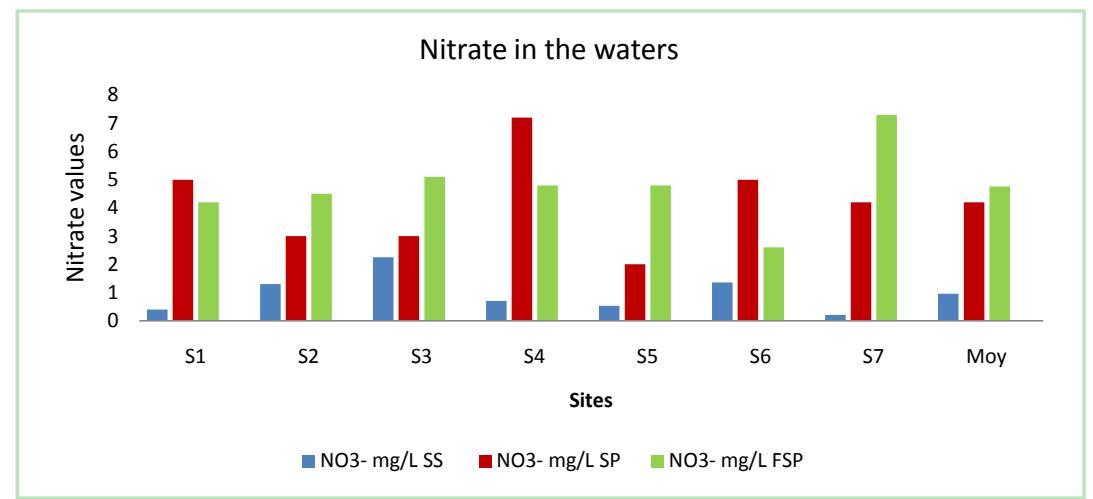

Figure 4. Nitrate values.

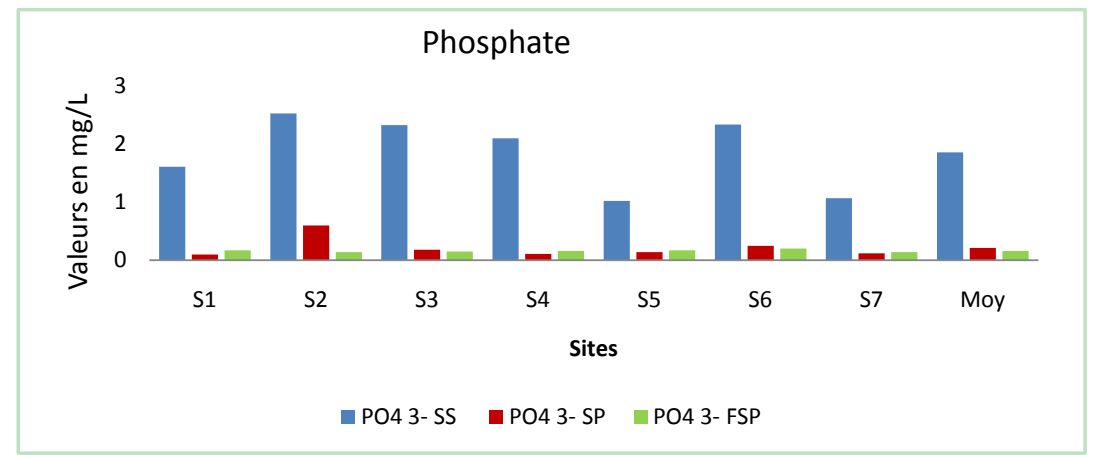

Figure 5. the values of phosphate $\left(\mathrm{PO}_{4}^{3-}\right)$.

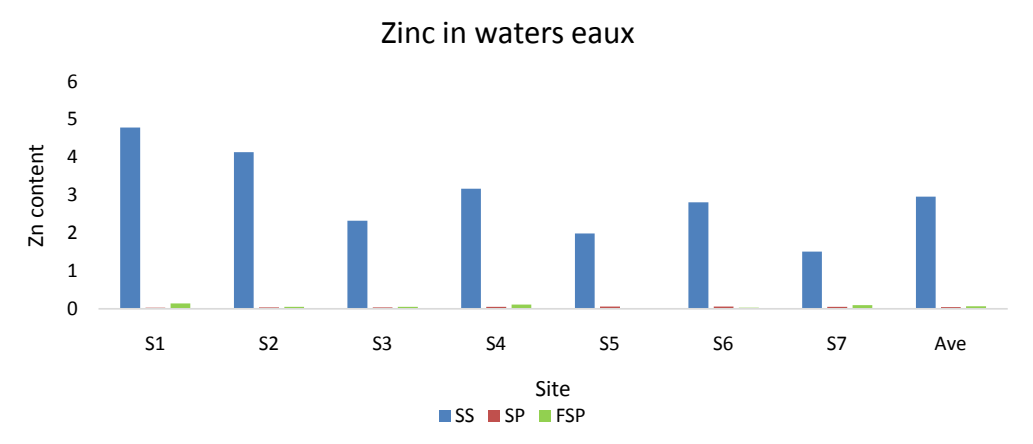

Figure 6. Zn content in the water. 


\section{Copper in the waters}

Copper concentrations in the river's waters were very low whatever the season with the exception of the sites S3 and S6 of which copper concentrations at the end of the rainy season were superior to $47.60 \mathrm{mg} \cdot \mathrm{L}^{-1}$ and $55.60 \mathrm{mg} \cdot \mathrm{L}^{-1}$, respectively (Figure 7). The copper concentrations in the river's water at the sites $\mathrm{S} 3$ and $\mathrm{S} 6$ were over the standards set for heavy metal concentrations in surface water (EC Directive) $\left(\mathrm{mg} \cdot \mathrm{L}^{-1}\right)$.

\section{$\checkmark$ Lead in the waters}

Figure 8 shows that the Concentrations of $\mathrm{Pb}$ in the waters of the river during the dry season were superior to the standards set by the IBGE and for heavy metal concentrations in surface waters (EC Directive) $\left(0.05 \mathrm{mg} \cdot \mathrm{L}^{-1}\right)$.

\section{Cadmium in the waters}

From Figure 9 the Cadmium concentrations in the river's waters were low during the rainy season with the exception of the site 2 of which cadmium concentrations was $4.32 \mathrm{mg} \cdot \mathrm{L}^{-1}$. During the dry season, cadmium concentrations in the river's water were over the standards set by the IBGE and for heavy metal concentrations in surface waters (EC Directive) $\left(0.005 \mathrm{mg} \cdot \mathrm{L}^{-1}\right)$.

\section{Sediment}

\section{$\checkmark \mathrm{Zn}$ in the sediment}

The concentrations of the $\mathrm{Zn}$ in sediments during the rainy season are higher than in the dry season (Figure 10). They vary from 102.00 to $175.00 \mathrm{mg} \cdot \mathrm{kg}^{-1}$ during the rainy season, from 20.00 to $35.00 \mathrm{mg} \cdot \mathrm{kg}^{-1}$ at the end of the rainy season and 0.01 to $15.6 \mathrm{mg} \cdot \mathrm{kg}^{-1}$ in the dry season. The concentrations of the $\mathrm{Zn}$ in sediments during the rainy season exceeded France standards $\left(80.00 \mathrm{mg} \cdot \mathrm{kg}^{-1}\right)$.

\section{Copper in the sediment}

Copper concentrations in sediments during the rainy season were higher than in the dry season (Figure 11). They varied from 69.00 to $231.00 \mathrm{mg} \cdot \mathrm{kg}^{-1}$ in the rainy season, which were superior to the France standards $\left(26 \mathrm{mg} \cdot \mathrm{kg}^{-1}\right)$.

\section{Lead in sediment}

Concentrations of $\mathrm{Pb}$ in sediments were high during and at the end of the rainy season at sites S1 $\left(9.42-18.32 \mathrm{mg} \cdot \mathrm{kg}^{-1}\right)$ and S2 $\left(20.58-14.40 \mathrm{mg} \cdot \mathrm{kg}^{-1}\right)$, and in the dry season at sites S6 (4.05 $\left.\mathrm{mg} \cdot \mathrm{kg}^{-1}\right)$ and S7 (23.00 $\left.\mathrm{mg} \cdot \mathrm{kg}^{-1}\right)$ (Figure 12). Lead concentrations in sediments were lower than France standards (22 $\mathrm{mg} \cdot \mathrm{kg}^{-1}$ ) with the exception of site $\mathrm{S} 7$ where the $\mathrm{Pb}$ concentrations in sediments during the dry season.

\section{$\checkmark$ Cadmium in the sediment}

Figure 13 shows that the Concentrations of $\mathrm{Cd}$ in sediments were 52.50 $\mathrm{mg} \cdot \mathrm{kg}^{-1}$ during the rainy season at the site $\mathrm{S} 7$ and $10.50 \mathrm{mg} \cdot \mathrm{kg}^{-1}$ during the dry season at the site S6. They were low at other sites. In contrast to river's waters at the sites S6 and S7, the presence of metal in the sediment is related to the bioavailable fraction.

\section{Discussion}

The vulnerability of rivers in the cotton zone of Benin is in increase, due to the 


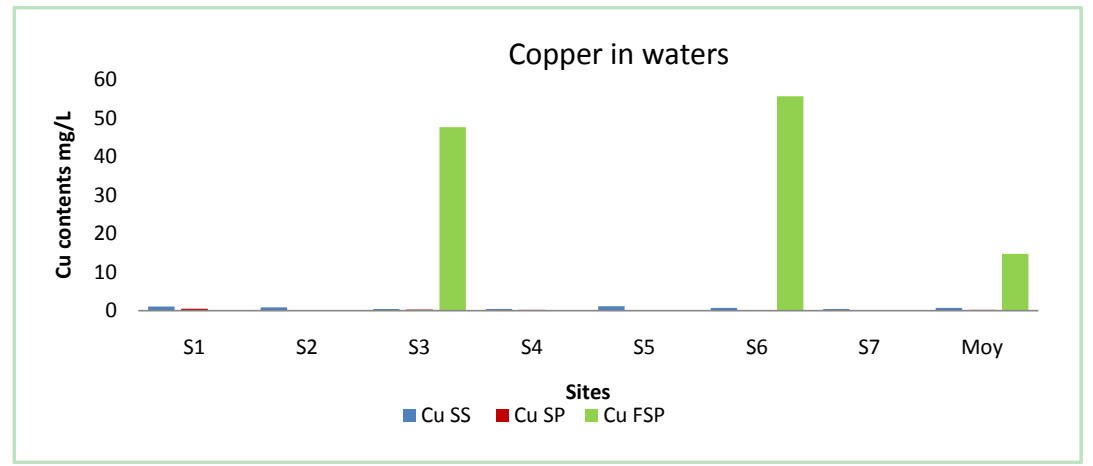

Figure 7. $\mathrm{Cu}$ content in the waters.

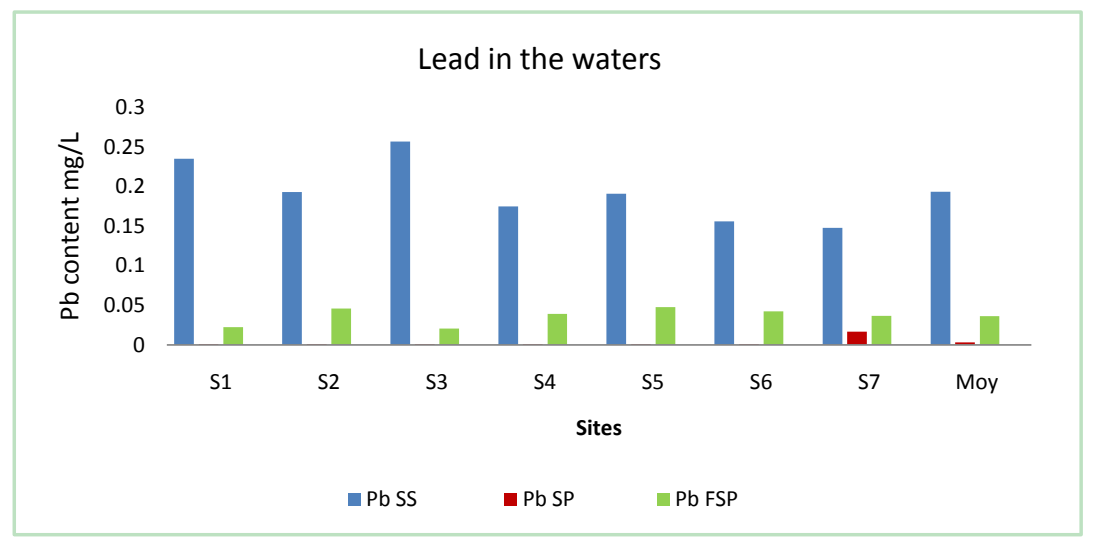

Figure $8 . \mathrm{Pb}$ content in the waters.

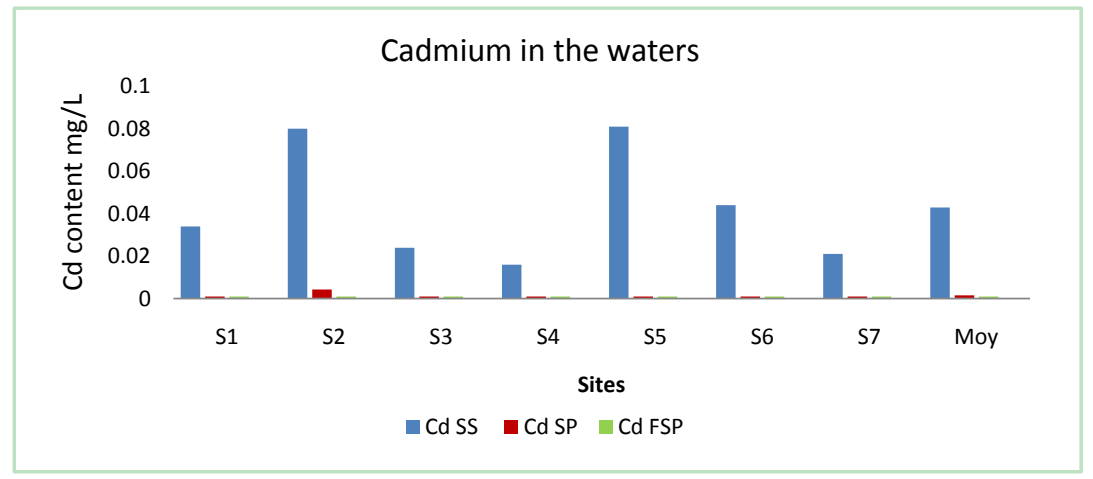

Figure 9. Content of Cd in waters.

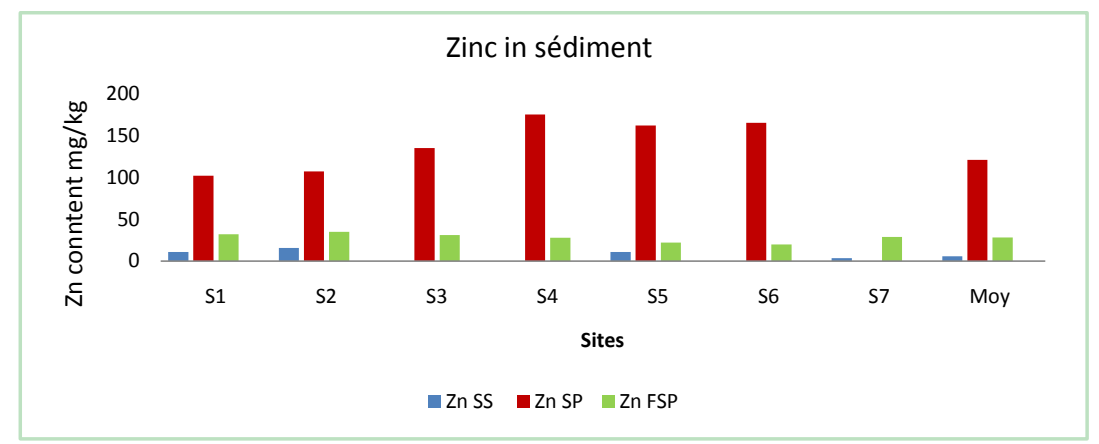

Figure $10 . \mathrm{Zn}$ content in sediments. 


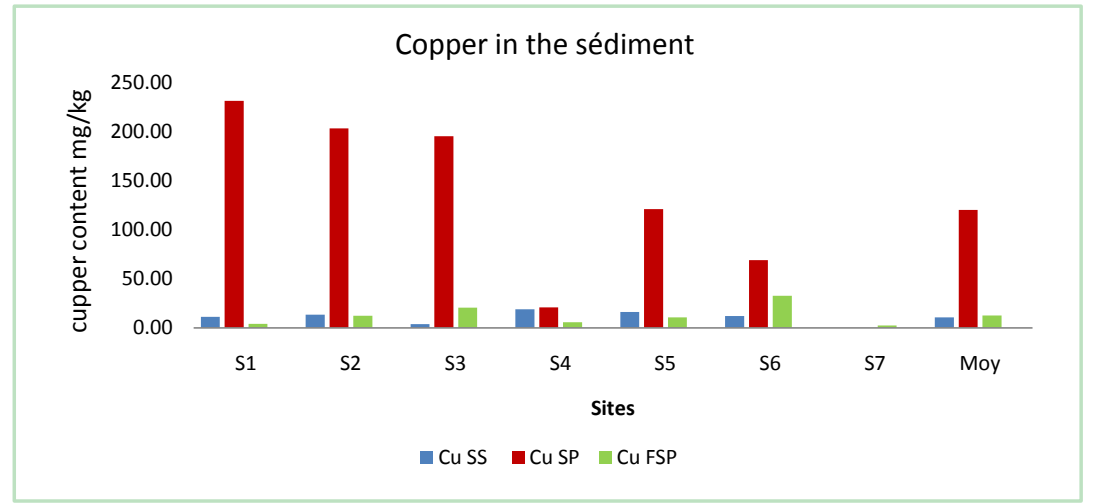

Figure 11. Cu content in sediments.

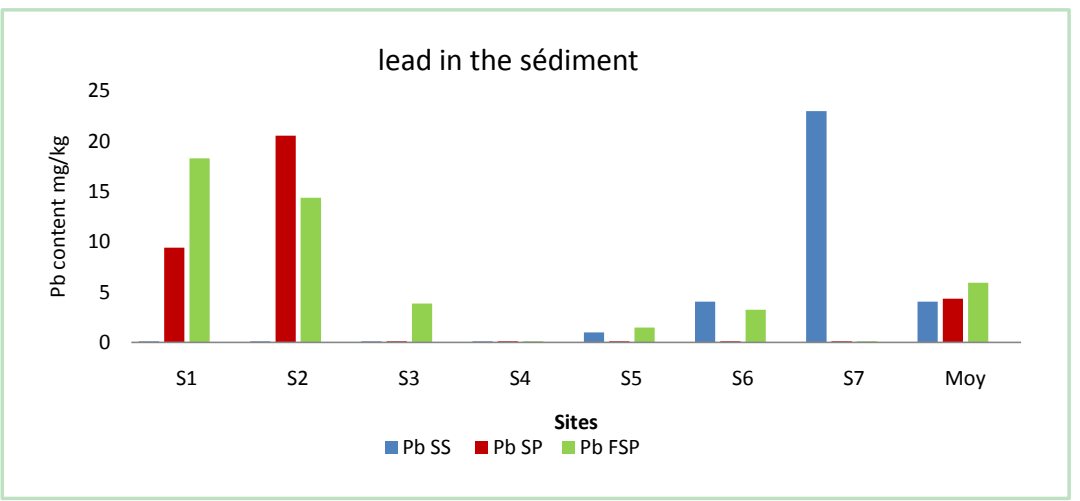

Figure $12 . \mathrm{Pb}$ levels in sediments.

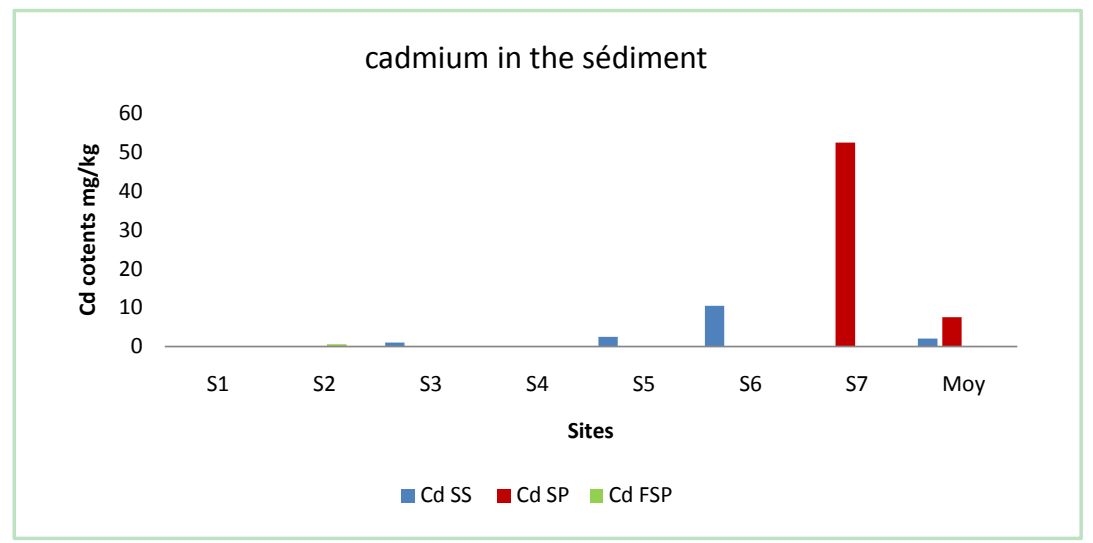

Figure 13. Cd contents in sediments.

common and intensive use of chemical fertilizers and pesticides, which are known to exhibit harmful effects on the environment (soil, air, surface water and underground). Surface waters are the most vulnerable to pollution resulting from the use of these chemical products.

The average temperatures recorded were $31.47^{\circ} \mathrm{C}$ in the dry season, $27.02^{\circ} \mathrm{C}$ during the rainy season and $26.26^{\circ} \mathrm{C}$, which were lower than the temperature of $28^{\circ} \mathrm{C}$ found in 2012 for the same river [21] at the end of the rainy season in the period from October to December. In agreement with the present study, rec- 
orded temperatures of $21.00^{\circ} \mathrm{C}$ to $25.40^{\circ} \mathrm{C}$ in the rainy season and $30.10^{\circ} \mathrm{C}$ to $32.10^{\circ} \mathrm{C}$ in the season dry in 2002 in ponds, rivers and hunting zones of the reserve of $\mathrm{W}$ and its hunting. Djibril (2002) reported temperatures of $27.94^{\circ} \mathrm{C}$ to $28.20^{\circ} \mathrm{C}$ for the waters from ponds and rivers of the Biosphere Reserve of Pendjari in 2002 [22], and Bassirou reported temperatures of $21.60^{\circ} \mathrm{C}$ to $26.40^{\circ} \mathrm{C}$ for the Niger River in 2003, which are consistent with our results as regards temperatures measured during the rainy season. The observed increase of the temperature in the dry season is related to climate; it can lead to a reduction in gases solubility in water including oxygen and influence water density. According to the France standards $\left(26.50^{\circ} \mathrm{C} ; 35.00^{\circ} \mathrm{C}\right)$ and Dedjiho (2011), various temperatures recorded exhibit no effect on the growth of aquatic species [23].

The temperature influences the $\mathrm{pH}$ of a solution, which is an important parameter in the assessment of water quality and the form of certain chemical species. The $\mathrm{pH}$ indicates the quantity of ions $\mathrm{H}_{3} \mathrm{O}^{+}$as well as the nature of the solution. The average values of the $\mathrm{pH}$ recorded in river's waters were 6.48 in the dry season, 6.71 in the rainy season and 7.24 at the end of the rainy season. The low $\mathrm{pH}$ observed in the dry season may be due to a decrease in the volume and the increase in the temperature of the river's waters. The recorded $\mathrm{pH}$ is lower than those reported by Agblonon; in 2012 for the same river [21] and Soclo in 2003 for the pools and rivers of the $\mathrm{W}$ reserve and its hunting areas [2]. These differences may arise due to differences in the amount of the chemical substances resulting from an intensive use of chemical fertilizers and pesticides during those years. Our results are also slightly lower than the $\mathrm{pH}$ found by Chouti in 2016 for the coastal lagoon (7.32) [24] and the river Mono (7.76) in 2018 [25], and that recorded by Wahalaa in 2016 for the river Litani in Lebanon (7.70) [26], where agriculture activities were not developed.

The present study reveals the average concentrations in nitrite in Alibori river's waters were $6.72 \mathrm{mg} \cdot \mathrm{L}^{-1}$ in the rainy season and $3.57 \mathrm{mg} \cdot \mathrm{L}^{-1}$ at the end of the season rainy. They are higher than those measured by Agblonon in 2012 in the same river's waters $\left(0.04 \mathrm{mg} \cdot \mathrm{L}^{-1}\right)$ [25], Soclo in 2003 in the pools and rivers of the $\mathrm{W}$ reserve and its hunting areas $\left(0.08 \mathrm{mg} \cdot \mathrm{L}^{-1}-0.56 \mathrm{mg} \cdot \mathrm{L}^{-1}\right)$ [2] and Djibril in 2002 in the same zone $\left(0.31 \mathrm{mg} \cdot \mathrm{L}^{-1}-200 \mathrm{mg} \cdot \mathrm{L}^{-1}\right)$ [22]. The divergence between our results and these previous studies conducted in the same region and season may be due to the increase in the chemical fertilizers and pesticides amount used and cropland area during the recent years.

Our results also contradict other authors who reported the concentrations in nitrite of $0.002-0.005 \mathrm{mg} \cdot \mathrm{L}^{-1}$ for waters from an affluent of the Alibori river known as Niger River in 2006 (Bassirou, 2009) [27], and $0.13 \mathrm{mg} \cdot \mathrm{L}^{-1}$ for waters from the delta of the Ouémé River [28].

The average nitrate concentrations in the river's waters were $0.96 \mathrm{mg} \cdot \mathrm{L}^{-1}$ during the dry season, $4.20 \mathrm{mg} \cdot \mathrm{L}^{-1}$ during the rainy season and $4.76 \mathrm{mg} \cdot \mathrm{L}^{-1}$ at the end of the rainy season, which suggest a lack of oxygen necessary for the oxidation of the nitrite ions to nitrate by Nitrobacter. The author previously reported that nitrification and dénitrification reactions were incomplete in some water 
rich in nitrite and classified that kind of water suspicious. Thus, the findings from the current study indicate a pollution of the waters from Alibori River by nitrite during cultivation period. The observed decrease in nitrite concentration and increase in nitrate concentration in Alibori river's waters at the end of the rainy season may be due to a slow oxidation of the nitrites ions to nitrate [29] [30] [31]. The authors reported in their previous works that eutrophication and degradation of organic matter may lead to oxygen deficiency and hence the limitation of the nitrification reaction. Nitrites are specifically harmful to young fishes and cause a dramatic drop in oxygen in the environment up to anoxia, which entailed a loss of biodiversity [29]. The observed disappearance of certain species in waters of Alibori River in 2012 by Agblonon [25].

Besides nitrite and nitrate, phosphate ions are part of elements responsible for eutrophication. The average concentrations of phosphate ions measured in waters of the Alibori River were $1.86 \mathrm{mg} \cdot \mathrm{L}^{-1}$ in dry season, $0.21 \mathrm{mg} \cdot \mathrm{L}^{-1}$ during the rainy season and $0.16 \mathrm{mg} \cdot \mathrm{L}^{-1}$ at the end of the rainy season. They are over 0.10 $\mathrm{mg} \cdot \mathrm{L}^{-1}$ and may cause eutrophication in waters of the Alibori River.

In sum, the relatively high concentrations of nitrite and phosphate in the waters of Alibori River are pollution indexes and may make their quality unfit for drinking, aquatic life and watering animals.

The average concentrations of $\mathrm{Zn}$ and $\mathrm{Cu}$ in the waters of the Alibori River were, respectively, $2.96 \mathrm{mg} \cdot \mathrm{L}^{-1}$ and $0.72 \mathrm{mg} \cdot \mathrm{L}^{-1}$ in the dry season, $0.05 \mathrm{mg} \cdot \mathrm{L}^{-1}$ and $0.19 \mathrm{mg} \cdot \mathrm{L}^{-1}$ in the rainy season, and $0.07 \mathrm{mg} \cdot \mathrm{L}^{-1}$ and $14.74 \mathrm{mg} \cdot \mathrm{L}^{-1}$ at the end of the rainy season. In the sediments, the average concentrations of $\mathrm{Zn}$ and $\mathrm{Cu}$ were, respectively, $5.90 \mathrm{mg} \cdot \mathrm{kg}^{-1}$ and $10.85 \mathrm{mg} \cdot \mathrm{kg}^{-1}$ in the dry season, $121 \mathrm{mg} \cdot \mathrm{kg}^{-1}$ and $120 \mathrm{mg} \cdot \mathrm{kg}^{-1}$ during the rainy season and $28.14 \mathrm{mg} \cdot \mathrm{kg}^{-1}$ and $12.61 \mathrm{mg} \cdot \mathrm{kg}^{-1}$ at the end of the rainy season. Our results reveal that metals such as $\mathrm{Zn}, \mathrm{Cu}, \mathrm{Cd}$ and $\mathrm{Pb}$ were more concentrated in sediments during the rainy season, which may be explained by the fact that they are bound to organic matter mixed into the soil and drained by run-off in the river and also depend on the $\mathrm{pH}$ of the environment. The MTC is released in the water along with organic maters degradation, entailing the increase of their concentrations during the dry season. The highest concentrations of the MTC were recorded at the sites highly populated and dominated by the cultivation of the river bank without the recommended minimum interval. The concentrations in $\mathrm{Zn}$ and $\mathrm{Cu}$ in waters and sediments from Alibori river recorded here were higher than those measured in coastal lagoon in $2016\left(\mathrm{Zn}: 0.15 \mathrm{mg} \cdot \mathrm{L}^{-1}\right.$ and $64.40 \mathrm{mg} \cdot \mathrm{kg}^{-1}$; $\mathrm{Cu}: 0.13 \mathrm{mg} \cdot \mathrm{L}^{-1}$ and 27.23 $\mathrm{mg} \cdot \mathrm{Kg}^{-1}$ ) by Chouti [28]. These differences may arise due to the use of the chemical fertilizers and pesticides for agriculture purposes as the river is located in a rural area dominated by agricultural activities.

\section{Conclusion}

This study has enabled a better understanding of the degree of pollution of the Alibori River. The results reveal that the physico-chemical parameters of the river's water and sediments did not meet almost all the standards. Thus, the wa- 
ters and sediment of the Alibori river were of poor quality and hence unfit for aquatic species and fauna whatever the period. The river of Alibori was polluted by metal since concentrations of the waters and sediments in TMC $(\mathrm{Cu}, \mathrm{Zn}, \mathrm{Pb}$, Cd) exceeded the standards set for aquatic species protection and drinking water. The concentrations of the nitrites in the river's water and sediments were over the standards in the cultivation period during the rainy season due to the intensive use of chemical fertilizers and pesticides for agriculture purposes. However, a better assessment of the chemical fertilizers and pesticides' impacts on the environment in the region requires the evaluation of the availability of pesticides in the different matrices, the mobility of MTC and their transfers in the food chain.

\section{Conflicts of Interest}

The authors declare no conflicts of interest regarding the publication of this paper.

\section{References}

[1] Haddad, H. and Ghoualem, H. (2014) Physico-Chemical Characterization of the Waters from Algerian Coastal Watershed. 155-167.

[2] Soclo (2003) Impact Study of the Use of Chemical Fertilizers and Pesticides Used by the Populations Living Near the Ecosystems (Surface Water, Plants and Fauna) of the Protected Areas (National Parks and Hunting Areas) of Benin. https://www.cenagref.org

[3] Vaissayre, M. and Cretenet, M. (2008) Environmental Risks Related to Cotton Cultivation in Francophone Africa: Assessment and Current Developments. ICAC 67-Ouagadougou Environmental Risk in Cotton Production. Pakistan Journal of Chemistry, 4, 49-61.

[4] AIC (Interprofessional Association of Cotton) (2006) Statistics of Cotton Production in Benin.

[5] Carson, R.L. (1962) Silent Spring. Riverside Press, Cambridge, MA.

[6] Adjagodo, A., Agassounon Djikpo Tchibozo, M., C. Kelome Ahouangnivo, N. and Lawani, R. (2016) Flux of Pollutants Related to Anthropic Activity and Risks on Surface Water Resources around the World (Bibliographic Synthesis). Larhyss Journal, 28, 7-23.

[7] Bazoma, B. (2014) Environmental Risks Related to the Use of the Pesticide in Two Agro Ecosystems Based on Conventional Cotton and Organic Cotton in Komplan, Dano Municipality, Burkina-Faso.

[8] Agbohessi, T.P., Toko, I.I. and Kestemont, P. (2012) Inventory of Contamination of Aquatic Ecosystems by Organochlorine Pesticides in the Benin Cotton Area. Cahiers Agricultures, 21, 46-56. https://doi.org/10.1684/agr.2012.0535

[9] Agbohessi, P.T., Imorou Toko, I., Attakpa, E.Y. and Kestemont, P. (2011) Characterization of Chemical Pesticides Used in Cotton Production and Impact on Economic Indicators in the Banikoara Municipality in North of Benin. International Journal of Biological and Chemical Sciences, 5, 1828-1841. https://doi.org/10.4314/ijbcs.v5i5.6

[10] Mamy, L., Barriuso, E. and Gabrielle, B. (2008) Evaluer les risques environnemen- 
taux des pesticides. Exemple du désherbage des cultures résistantes ou non au glyphosate. Innovations Agronomiques, 3, 121-143.

[11] Ometo, J.P.H.B., Martinelli, L.A., Ballester, M.V., Gessner, A., Krusche, A.V., Victoria, R.L. and Williams, M. (2000) Effects of Land Use on Water Chemistry and Macroinvertebrates in Two Streams of the Piracicaba River Basin, Southeast Brazil. Freshwater Biology, 44, 327-337. https://doi.org/10.1046/j.1365-2427.2000.00557.x

[12] Piscart, C., Moreteau, J.C. and Beisel, J.N. (2005) Biodiversity and Structure of Macroinvertebrate Communities along a Small Permanent Salinity Gradient (Meurthe River, France). Hydrobiology, 551, 227-236. https://doi.org/10.1007/s10750-005-4463-0

[13] Tarr, T.L., Baber, M.J. and Babbitt, K.J. (2005) Macroinvertebrate Community Structure across a Wetland Hydroperiod Gradient in Southern New Hampshire, USA. Wetlands Ecology and Management, 13,321-334. https://doi.org/10.1007/s11273-004-7525-6

[14] Nziguheba, G. and Smolders, E. (2008) Inputs of Trace Elements in Agricultural Soils via Phosphate Fertilizers in European Countries. Science of The Total Environment, 390, 53-57. https://doi.org/10.1016/j.scitotenv.2007.09.031

[15] Yamaguchi, N., Kawasaki, A. and Iiyama, I. (2009) Distribution of Uranium in Soil Components of Agricultural Fields after Long-Term Application of Phosphate Fertilizers. Science of The Total Environment, 407, 1383-1390. https://doi.org/10.1016/j.scitotenv.2008.10.011

[16] Chouti, W.K. (2011) Study of the Chemical Pollution of a Tropical Lagoon (Water, Sediments, Fishes) Case of the Lagoon of Porto-Novo (Southern Benin). Thesis, 100.

[17] Hayzoun, H. (2014) Characterization and Quantification of the Anthropogenic and Industrial Pollution Load in the Sebou Watershed Thesis.

[18] Sigg, L., Behra, P. and Stumm, W. (2006) Chemistry of Aquatic Environments. Natural Water Chemistry and Interfaces in the Environment. 4th Edition, Dunod, Paris, 564 p.

[19] Barjhoux, I. (2011) Study of the Bioavailability and Toxicity of Chemical Pollutants at Risk in Aquatic Sediments with Regards to the Early Stages of Development of a Model Fish.

[20] Bliefert, C. and Perraud, R. (2001) Environment of Chemical: Air, Water, Soils, Waste. Paris.

[21] Agblonon Houelome, T.M., Adandedjan, D., Chikou, A., Toko, I.I., Bonou, C., Youssao, I. and Lalèyè, P. (2016) Assessment of the Quality of Stream Water of the Middle Course of the Alibori River by the Study of the Macro-Benthic Invertebrates in the Cotton Area of Benin (West Africa). International Journal of Biological and Chemical Sciences, 10, 2461-2476. https://doi.org/10.4314/ijbcs.v10i6.5

[22] Djibril, B.R. (2002) Contribution of the Impact Study to the Use of the Chemical Fertilizer and Pesticides in the Quality of Water in the Reserve of Biosphere of the Pendjari. End of Training Thesis, Engineer in Works of Development Techniques and Environment, Protection APE/CPU.

[23] Dèdjiho, A. (2011) Assessment of the Trophic Chain of Marine Air Protection in Relation to Its Physico-Chemistry: Case of Gbèzoumè in the Community of Ouidah. Memory of DEA. FAST/UAC, Benin.

[24] Chouti, W., Chitou, N., Kelome, N., Kpako, B.H., Honvou Vlavonou, D. and Tossou, M. (2017) Physico-Chemical Characterizations and Toxicity Study of Côtière 
Lagoon, of Togbin to Grand-Popo (Sud-Ouest Bénin). European Scientific Journal Edition, 13, 131-151. https://doi.org/10.19044/esj.2017.v13n27p131

[25] Chouti, W.K. and Hounkpèvi, E. (2018) Chemical Quality and Bacteriology the Waters of the Mono rivère, south-ouest Bénin. Afrique Science, 14, 23-32. http://www.afriquescience.net

[26] Wahalaa, D.I.A.B. (2016) Study of the Physicochemical Properties and Colloidal of the Litani River Basin, Lebanon. 213 p.

[27] Alhou, B., Micha, J.-C., Dodo, A. and Waiss, A.A. (2009) Study of the Physico-Chemical and Biological Quality of Waters of the Niger River in Niamey. International Journal of Biological and Chemical Sciences, 3, 240-254.

https://doi.org/10.4314/ijbcs.v3i2.44489

[28] Zinsou, H., Attingli, A., Gnohossou, P., Adandedjan, D. and Lalèyè, P. (2016) Caractéristiques physico-chimiques et pollution de l'eau du Delta de l'Ouémé au Bénin. Journal of Applied Biosciences, 97, 9163-9173.

https://doi.org/10.4314/jab.v97i1.3

[29] Hébert, S. and Légaré, S. (2000) Monitoring the Quality of the Rivers Water and Small Courses. Ministry of Sustainable Development, Environment and Parks, State of the Environment Monitoring Directorate, $72 \mathrm{p}$.

[30] Diaz, R.J. (2001) Overview of Hypoxia around World. Journal of Environmental Quality, 30, 275-281.

[31] Hulla, V., Parrell, L. and Falcucci, M. (2008) Modelling Dissolved Oxygen Dynamics in Coastal Lagoons. Ecological Modelling, 211, 468-480.

https://doi.org/10.1016/j.ecolmodel.2007.09.023 